\title{
Minangkabau Language Mapping Verification in West Sumatra Province
}

\author{
Rita Novita ${ }^{1}$ * Winci Firdaus ${ }^{2}$, Satwiko Budiono ${ }^{3}$

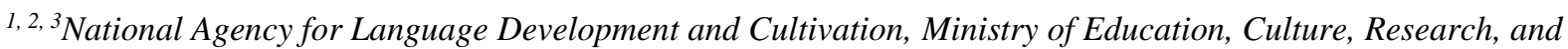 \\ Technology \\ "Corresponding author. Email: lesha_one@yahoo.com
}

\begin{abstract}
The use of language has differences depending on geographical conditions and the surrounding environment. This is due to the use of language like waves so that language changes or variations are unavoidable. What's more, the presence of different language contacts makes changes or variations of the language also different. One example of an interesting language in terms of language use is the Minangkabau language. In this case, the Minangkabau language in West Sumatra Province has a wide area of language usage and many borders with other provinces. In addition, the differences in the results of the Minangkabau language research in West Sumatra Province also add to the attractiveness of further research efforts as verification of the various findings. In connection with that matter, verification of Minangkabau language mapping in West Sumatra Province is important. It aims to see the limits of the use of the Minangkabau language in the form of maps and to compare the data according to the closest distance between the observation areas. This study uses a dialectological approach with quantitative and qualitative methods. The quantitative method is based on dialectometric calculations, while the qualitative method is based on the analysis of the dialectometry calculations. The data compared in this study is the result of language mapping from the Language Center of West Sumatra Province with 400 vocabularies as a list of questions. The observation area chosen in this study is the area of the use of the Minangkabau language which has a both different dialects and new areas that have not been compared from previous studies. The addition of new observation areas for comparison in this study is the Lunang isolect in Pesisir Selatan Regency and the Sungai Limau isolect in Dharmasraya Regency. As a result, the Minangkabau language only has two dialects, namely the Agam-Tanah Datar dialect and Pancung Soal dialect with the percentage of dialectometry calculation results of $51-80 \%$. The Agam-Tanah Datar dialect consists of the Payakumbuh, Limapuluh Kota, Pangkalan Koto Baru, Pasaman, and Tarung-Tarung Rao sub-dialects, while the Pancung Soal dialect consists of the Koto Baru, Dharmasraya, and Lunang sub-dialects. The sub-dialect classification can be seen from the results of the $31-50 \%$ dialectometry calculation.
\end{abstract}

Keywords: Minangkabau Language, Verification of Language Mapping, Language Usage, Dialectology.

\section{INTRODUCTION}

The use of language has differences depending on geographical conditions and the surrounding environment. This is due to the use of language like waves so that language changes or variations are unavoidable. In this case, the further the use of language from the area of distribution, the more different the use of the language can be understood. Schmidt Budiono [1] explains that the languages in a region have the influence of change in a particular place. From this statement, geographical conditions are one of the determining factors for changes in language use. Not only that, Eckert [2] also explained that there are three waves of language variation, namely (1) social stratification, (2) ethnographic elements, and (3) stylistic perspective. The determinants of language use in terms of social stratification referred to by Eckert are socio-economic class, gender, ethnicity, and age. In addition, other factors that also influence the use of language are ethnographic elements. This is because the category and local configuration of a group can be different so that the use of language is also related to this. Different from other factors, this stylistic factor is 
closely related to social problems in a group so that the context, construction, and social meaning are different so that the use of language can also be different. Some of the factors of Eckert [2] can be categorized in the surrounding environmental factors so that it affects the use of the language.

One example of an interesting language in terms of language use is the Minangkabau language. This is because the Minangkabau language in West Sumatra Province has a wide area of language usage and many borders with other provinces. West Sumatra Province is directly adjacent to North Sumatra Province in the north, Riau Province in the east, and Jambi and Bengkulu Provinces in the south. Meanwhile, West Sumatra Province is directly adjacent to the Indian Ocean in the west. The location of West Sumatra Province which is directly adjacent to four other provinces on the island of Sumatra naturally makes the use of the language have differences or variations. The distance between one region and another in the province of West Sumatra which is far apart along with the proximity of the province of West Sumatra to other provinces makes language contact between speakers of Minangkabau language and speakers of other languages unavoidable. The following map shows the geographical location of the Province of West Sumatra.

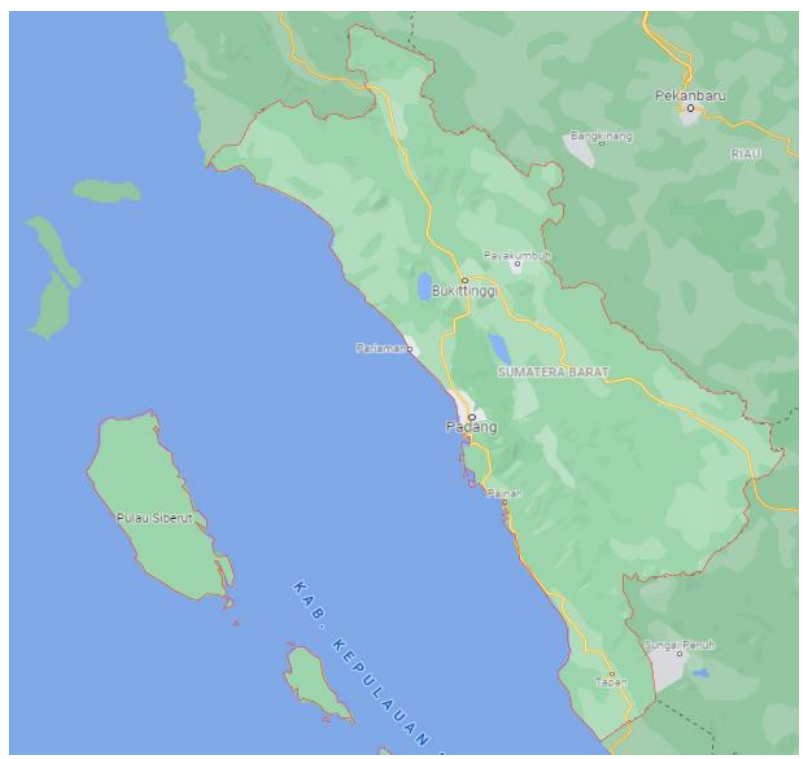

Figure 1 Map of West Sumatra Province (Source: Google Maps).

In addition, the differences in the results of the Minangkabau language research in West Sumatra Province also add to the attractiveness of further research efforts as an effort to verify the various findings that previously existed. This is based on previous research on mapping the Minangkabau language which has differences. Starting from Maksan et al. [3], Wahyudi [4], until Sunendar [5]. Study Maksan, et al. [3] seeks to map the Minangkabau language in the Pesisir Selatan Regency, West Sumatra Province. The observation area is as many as twenty five nagari or villages by comparing the closest observation area only. However, the list of questions compared is only 200 Swadesh vocabulary. The results of the study explain the phonetic and morphological variations of the Minangkabau language in the Pesisir Selatan Regency. In addition, this study also produced a language map with one Minangkabau dialect, namely the Pancung Soal dialect. However, the scope of this research is limited to the district level. This is different from this study which has a provincial level scope and produces a map of the Minangkabau language in West Sumatra Province.

After that, there was research Wahyudi, et al. [4] who did the mapping of languages in West Sumatra Province. In his findings, Wahyudi explained that there are four languages in West Sumatra Province, namely Minangkabau language, Mentawai language, Javanese language, and Mandailing language. In this case, the Minangkabau language has eight dialects, including the Pasaman dialect, the Tarung-Tarung Rao dialect, the Limapuluh Kota dialect, the Pangkalan Koto Baru dialect, the Payakumbuh dialect, the Agam-Tanah Datar dialect, the Koto Baru dialect, and the Pancung Soal dialect. The results of the study were obtained from comparing 400 vocabularies as a list of questions. In addition, research Wahyudi, et al [4] compare all observation areas even though the observation areas are far from each other. In fact, this study did not create a language map and only performed dialectometric calculations as a result. This is different from the verification of language mapping in this study, which only compares the closest observation areas through language maps so that the boundaries of the Minangkabau language can be clearly delineated.

Different from before, Sunendar [5] featuring five Minangkabau dialects, namely the Pasaman dialect, the Agam-Tanah Datar dialect, the Limapuluh Kota dialect, the Koto Baru dialect, and the Pancung Soal dialect. These results are known from the results of the dialectometry calculation as much as $51-69 \%$. What differentiates research Sunendar [5] with Wahyudi, et al. [4] is a map of languages in West Sumatra Province. However, the language map does not focus on the Minangkabau language. Meanwhile, all observation areas are compared in dialectometry calculations. This makes the map of languages in the province of West Sumatra certainly different from the map of the Minangkabau language in the province of West Sumatra. In this regard, several different previous research results require verification of the Minangkabau language mapping so that the linguistic situation and condition of the Minangkabau language can be described through language maps. Not only that, this study also aims to see the language boundaries of the Minangkabau language in West Sumatra Province in the 
form of a language map so that the number of dialect and subdialect classifications of the Minangkabau language can be verified clearly.

\section{METHODOLOGY}

This research is classified into dialectological research with quantitative and qualitative methods. The quantitative method is based on the results of the dialectometry calculation and the qualitative method is based on the analysis of the dialectometric calculation results. In addition, this study also attempted to create a map of the Minangkabau language in West Sumatra Province. The data compared in this study is the result of language mapping of West Sumatra Province Wahyudi, et al. [4] with 400 vocabulary as a list of questions. The vocabulary consists of basic Swadesh vocabulary, body parts vocabulary, kinship system vocabulary, movement and work vocabulary, and task vocabulary. Research result of Wahyudi, et al. [4] which suggests eight Minangkabau language dialects were taken as research data with the addition of two new data, namely the Lunang isolect in Pesisir Selatan Regency and the Sungai Limau isolect in Dharmasraya Regency. Thus, the total observation areas compared in this study were ten observation areas. The following is a list of observation areas in the verification of Minangkabau language mapping below.

Table 1. Minangkabau language mapping verification observation area in West Sumatra Province

\begin{tabular}{|l|l|l|}
\hline No & Isolect & Dialect \\
\hline 1 & Pariangan & Agam-Tanah Datar \\
\hline 2 & Balai Tongah Koto & Payakumbuh \\
\hline 3 & Sungai Naniang & Limapuluh Kota \\
\hline 4 & Koto Lamo & Pangkalan Koto Baru \\
\hline 5 & Ampang Kuranji & Koto Baru \\
\hline 6 & Sungai Limau & Not yet identified \\
\hline 7 & Tarung-Tarung & Tarung-Tarung Rao \\
\hline 8 & Padang Mantinggi & Pasaman \\
\hline 9 & Kudo Kudo Indrapura & Pancung Soal \\
\hline 10 & Lunang & Not yet identified \\
\hline
\end{tabular}

From the list of observation areas above, it can be seen that one dialect of the research results Wahyudi, et al. [4] represented by one isolect with the addition of two new isolects that have not been identified. This is intended to facilitate comparisons in this study. The results of this study can be used as verification material for previous studies so that the results of dialectometry calculations can be clearly described through language maps. The research steps from dialectometry calculations to language map creation are explained in more detail below.

\subsection{Dialectometry Calculations}

Comparison of the lexicon of 400 vocabularies as a list of questions in this study using a dialectometric calculation model. This is because the scope of research in the form of lexicon and phonological levels can be calculated by dialectometric calculations so that the differences between the observation areas become visible. Vocabulary mapping results from all areas of observation were compared and the difference was calculated using the Seguy formula (Lauder [6]) in this below.

$$
\underline{\mathrm{s} X 100}=\mathrm{d} \%
$$

$\mathrm{n}$

Information:

$\mathrm{s}$ : differential number from other observation areas

$\mathrm{n}$ : number of maps compared

$\mathrm{d}$ : vocabulary distance in percent $(\%)$

The results of this dialectometry calculation can consist of five categories, namely different languages, different dialects, different subdialects, different speeches, and no different languages. What distinguishes each category is the percentage value of the dialectometry calculation. The following is a list of the percentages obtained from dialectometry calculations and their categories according to Guiter formula (Lauder, [6]) as a reference in this research.

Table 2. Dialectometry calculation results table

\begin{tabular}{|l|l|l|}
\hline No & Language Status & Percentage (\%) \\
\hline 1 & Different Language & $>80 \%$ \\
\hline 2 & Different Dialect & $51-80 \%$ \\
\hline 3 & Different Subdialect & $31-50 \%$ \\
\hline 4 & Different Speech & $21-30 \%$ \\
\hline 5 & No Different Language & $<20 \%$ \\
\hline
\end{tabular}

\subsection{Language Map Making}

One thing that is no less important in this research is the creation of language maps. This is intended to determine the boundaries of the Minangkabau language in the province of West Sumatra. In this case, language boundaries with administrative boundaries cannot be equated because both have different approaches. Moreover, there has never been a Minangkabau language map in West Sumatra Province so that this language map can be a novelty in dialectological 
research. according to Ayatrohaedi [7], making a language map has several stages that are interrelated with each other. Starting from making a base map, making a numbering map of the observation area, making a triangular map of language, to making a spider web map based on the results of dialectometry calculations. All stages of making the map must be done sequentially. Errors in one stage can have an impact on errors in the next stage. For this reason, making this language map must be thorough and careful so that it can minimize errors that can hinder and prolong the next work step.

In making a base map, a map from Google Maps can be chosen as the basis by removing the regional names and various symbols in it and adding the cardinal directions, scales, and descriptions of regional boundaries. Furthermore, the numbering of the observation area consists of several numbering patterns. Starting from circular clockwise or vice versa, zigzag from top to bottom or vice versa, left to right or vice versa, to top to bottom or vice versa. The selection of the numbering pattern is adjusted to the situation and condition of the observation area and the geographical location of the observation area. After that, the observation areas that have been given a number are connected according to the closest distance to form a triangular pattern. In making language maps, The observation area that is connected by a triangular pattern is the basis for comparing the observation areas in dialectometry calculations. Finally, the percentage of the dialectometric calculation results is displayed in a spider web map by taking the center line in the triangular pattern of the language. That way, language boundaries can be clearly delineated through language maps.

\section{RESULTS AND DISCUSSION}

The results of this study lead to three things, namely (1) the results of dialectometry calculations, (2) the results of making language maps, and (3) the results of Minangkabau language mapping verification in West Sumatra Province. These three things can be the basis for a description of the situation and condition of the Minangkabau language in the province of West Sumatra. All are related to each other. Starting from the percentage of the results of the dialectometry calculation, it shows statistical differences in language use between the observation areas. Then, the quantitative results are described through a language map to make it easier to see the language use of the Minangkabau language in West Sumatra Province. Meanwhile, the result of language mapping verification aims to describing the percentage of the result of the dialectometry calculation and language mapping so that the data of dialectometry calculation and language mapping in this research can't misinterpreted.

\subsection{Dialectometry Calculation Results}

Table 3. Percentage of dialectometry calculation results

\begin{tabular}{|l|l|l|}
\hline $\begin{array}{l}\text { Observation } \\
\text { Area }\end{array}$ & Percentage & Results \\
\hline $1 / 2$ & $47.25 \%$ & Different Subdialect \\
\hline $1 / 3$ & $40.75 \%$ & Different Subdialect \\
\hline $1 / 5$ & $53.25 \%$ & Different Dialect \\
\hline $1 / 6$ & $51.50 \%$ & Different Dialect \\
\hline $1 / 9$ & $52 \%$ & Different Dialect \\
\hline $2 / 3$ & $40 \%$ & Different Subdialect \\
\hline $2 / 4$ & $49.25 \%$ & Different Subdialect \\
\hline $2 / 5$ & $57.25 \%$ & Different Dialect \\
\hline $3 / 4$ & $37.50 \%$ & Different Subdialect \\
\hline $3 / 7$ & $34.25 \%$ & Different Subdialect \\
\hline $4 / 5$ & $54.75 \%$ & Different Dialect \\
\hline $4 / 7$ & $41 \%$ & Different Subdialect \\
\hline $4 / 8$ & $40.50 \%$ & Different Subdialect \\
\hline $5 / 6$ & $38.75 \%$ & Different Subdialect \\
\hline $6 / 9$ & $37.75 \%$ & Different Subdialect \\
\hline $6 / 10$ & $33 \%$ & Different Subdialect \\
\hline $7 / 8$ & $33 \%$ & Different Subdialect \\
\hline $9 / 10$ & $43.25 \%$ & Different Subdialect \\
\hline
\end{tabular}

Table 4. List of the observation area

\begin{tabular}{|l|l|l|}
\hline No & Observation Area & Regency or City \\
\hline 1 & Pariangan & Tanah Datar \\
\hline 2 & Balai Tongah Koto & Tanah Datar \\
\hline 3 & Sungai Naniang & Limapuluh Kota \\
\hline 4 & Koto Lamo & Limapuluh Kota \\
\hline 5 & Ampang Kuranji & Dharmasraya \\
\hline 6 & Sungai Limau & Dharmasraya \\
\hline 7 & Tarung-Tarung & Pasaman \\
\hline 8 & Padang Mantinggi & Pasaman \\
\hline 9 & Kudo Kudo Inderapura & Pesisir Selatan \\
\hline 10 & Lunang & Pesisir Selatan \\
\hline
\end{tabular}

From the results of the percentage calculation of dialectometry above, it can be seen that most of the comparisons have different sub-dialect results between the observation areas. It is based on a percentage gain of $31-50 \%$. Meanwhile, there are five comparisons that have different dialect results between the areas of observation. The condition is based on the percentage gain of $51-70 \%$. However, the percentage gain of five comparisons that have different dialect results is not more than $58 \%$ and there are not necessarily five 
dialects in the Minangkabau language in West Sumatra Province. This is because the results of the dialectometry calculation must be stated in a language map first so that the situation and linguistic conditions of the Minangkabau language in West Sumatra Province can be seen clearly.

\subsection{Result of Making Language Map}

The Minangkabau language map in West Sumatra Province was obtained in several stages. Starting from the stage of making a base map, making a numbering map, making a triangular language map, to making a spider web map. All the results of each stage of map creation are shown below.

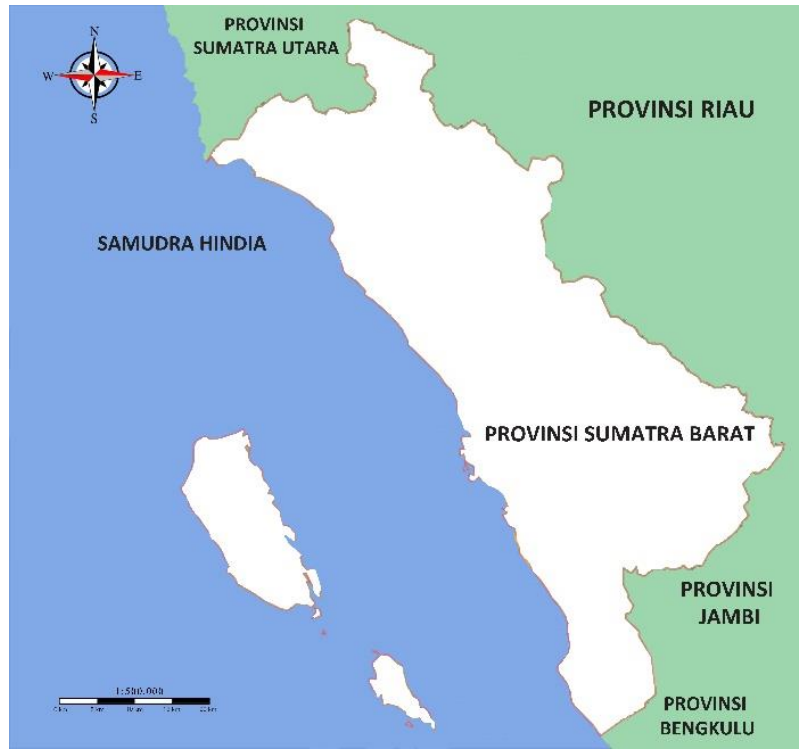

Figure 2 Base map of West Sumatra Province

In the base map above, it can be seen that the Province of West Sumatra which is the observation area in this study is marked in white color. Other provinces directly adjacent to West Sumatra Province, such as Bengkulu Province, Jambi Province, Riau Province, and North Sumatra Province are marked in green color. This also indicates that the province directly adjacent to the province of West Sumatra is land. This is different from the blue color on the base map which indicates the sea from the Hindia Ocean. In addition, the scale and cardinal directions were added to make it easier to see directions on this base map. Next, the base map is numbered according to the selected numbering pattern. The following is the result of the numbering map from West Sumatra Province.

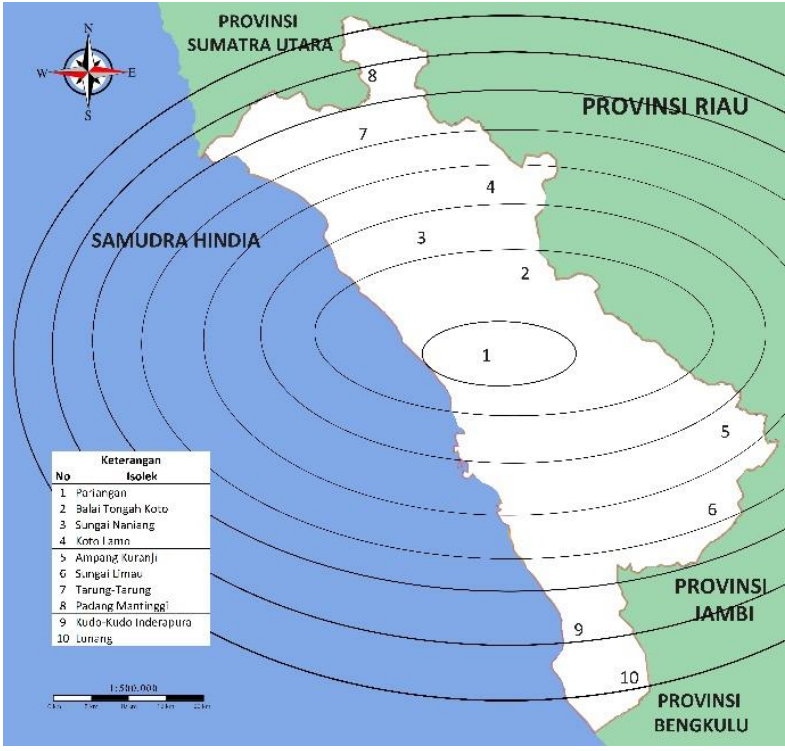

Figure 3 Numbering map of West Sumatra Province

The numbering pattern chosen according to the situation and conditions of the Minangkabau language in West Sumatra Province is circular in a clockwise direction. The first numbering is located on the Paringan isolect in Tanah Datar Regency. This is due to the use of the Minangkabau language, the Agam-Tanah Datar dialect, which is most widely used and is located in the middle of West Sumatra Province. It can be said that the location of the observation area which is far from the border area can still be assumed to be less contacted by other speakers and other cultures compared to the observation area which is close to the border of other regions. Numbering is ordered by distance so that the largest numbering belongs to the farthest observation area. After the numbering of the observation area is complete, the next step is to make a matrabasa triangular map.

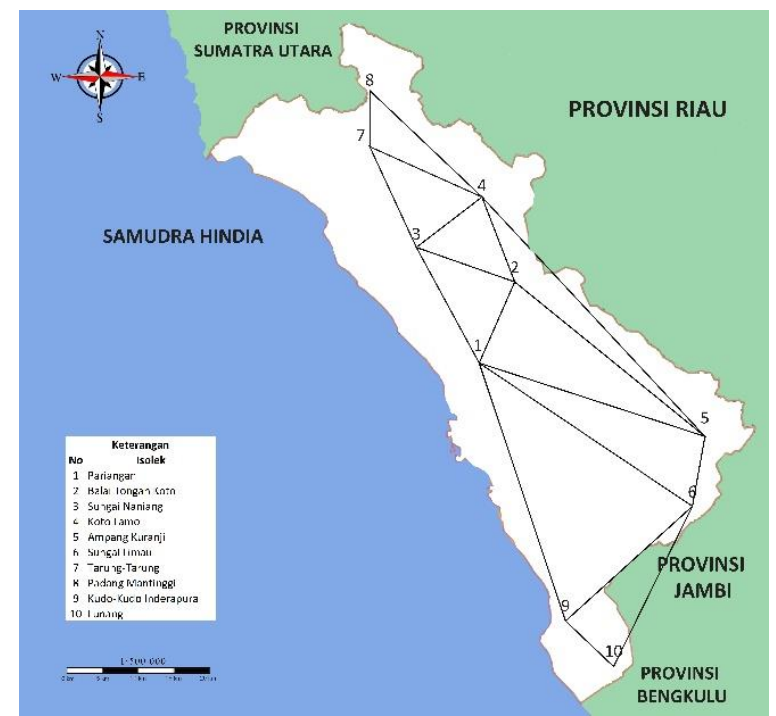

Figure 4 Matrabasa triangular map of West Sumatra Province 
The matrabasa triangular map above is a determinant of the comparison of dialectometry calculations. Only line-connected observation areas are compared in dialectometric calculations. This is because the triangular line of this language indicates that the observation area has a close distance. In this case, the observation areas that are far apart and are not connected by triangular lines are not compared in dialectometry calculations. After the percentage of the dialectometric calculation results is known, the next stage is making a spider web map. The results of the spider web map based on the percentage of dialectometric calculations can be seen below.

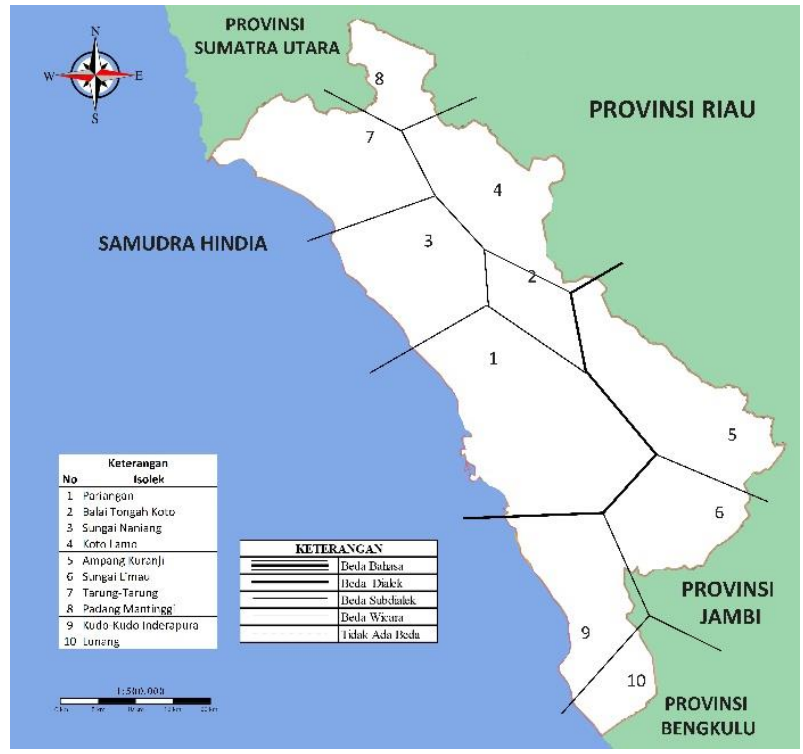

Figure 5 Map of spider webs of West Sumatra Province

In the spider web map above, it can be seen that there is only one thick line with different dialect categories that separates the observation areas numbered (5), (6), (9), and (10) from the observation area number (1), (2), (3), (4), (7), and (8). This can indicate that there are only two dialects in West Sumatra Province, namely the Agam-Tanah Datar dialect and the Pancung Soal dialect. The distribution area of the Agam-Tanah Datar dialect is located in the observation areas number (1), (2), (3), (4), (7), and (8). Meanwhile, the distribution area of the Pancung Soal dialect is located in the observation area number (5), (6), (9), and (10). This condition can be seen from the results of different subdialects in the observation areas numbered (1), (2), (3), (4), (7), and (8) which indicate one dialect. The same thing is also seen in the observation areas number (5), (6), (9), and (10) which different subdialect so that this observation areas indicate one dialect.

\subsection{Minangkabau Language Mapping Verification Results in West Sumatra Province}

To make it easier to know the results of the dialectometry calculations and language maps in the previous section, a description of the two results is important. This is intended so that there are no misintrepeted in describing the results of dialectometry calculations and maps of the Minangkabau language in West Sumatra Province. The description of these results also uses a classification table starting from language, dialect, and subdialect. Making this table aims to simplify the results of this study in order to facilitate understanding. The following table shows the results of the Minangkabau language mapping verification in West Sumatra Province.

Table 5. Minangkabau language mapping verification results

\begin{tabular}{|l|l|l|}
\hline Language & Dialect & Subdialect \\
\hline Minangkabau & $\begin{array}{l}\text { Pancung } \\
\text { Soal }\end{array}$ & Koto Baru \\
\cline { 3 - 3 } & & Sungai Limau \\
\cline { 2 - 3 } & \multirow{4}{*}{$\begin{array}{l}\text { Agam-Tanah } \\
\text { Datar }\end{array}$} & Lunang \\
& Payakumbuh \\
& Limapuluh Kota \\
& Pangkalan Koto Baru \\
& Pasaman \\
& & Tarung-Tarung Rao \\
\hline
\end{tabular}

From the table above, it can be seen that the Minangkabau language has two dialects, namely the Pancung Soal dialect and the Agam-Tanah Datar dialect. The Pancung Soal dialect has three subdialects, including the Koto Baru subdialect, the Sungai Limau subdialect, and the Lunang subdialect. Meanwhile, the Agam-Tanah Datar dialect has five subdialects, including the Payakumbuh subdialect, the Limapuluh Kota subdialect, the Pangkalan Koto Baru subdialect, the Pasaman subdialect, and the Tarung-Tarung Rao subdialect. These results are based on the results of dialectometry calculations and the results of the Minangkabau language map in West Sumatra Province. However, this result is different from the classification of languages and dialects of West Sumatra Provincial Government [8]. The following is a list of local government about language and dialect classifications.

Table 6. List of languages and dialects of local government

\begin{tabular}{|l|l|l|}
\hline No & Language & Dialect \\
\hline 1 & Minangkabau & Nagari Gunuang \\
\cline { 3 - 3 } & & Agam \\
& & Koto Nan Ompek- \\
& & Libukan-Aua Kuniang \\
& & Koto Nan Godang \\
& & Lamposi Tigo Nagori \\
\hline & & Tiaka \\
\hline
\end{tabular}




\begin{tabular}{|c|l|l|}
\hline No & Language & Dialect \\
\hline & & Payobasuang \\
\cline { 3 - 3 } & & Aia Tabik \\
\hline 2 & Dharmasraya & \\
\hline 3 & Tansi & \\
\hline 4 & Jawa & \\
\hline 5 & Batak & \\
\hline 6 & Sunda & \\
\hline 7 & Mandailing & \\
\hline 8 & Melayu & \\
\hline 9 & Mentawai & \\
\hline
\end{tabular}

Based on the list of languages and dialects of West Sumatra Provincial Government [8] above, it can be seen that the Province of West Sumatra has nine languages and the Minangkabau language has eight dialects. These results are based on public recognition only, so it is natural that there are differences with the research results. The interesting thing from the table above is that there are differences in the number and naming of dialects of the Minangkabau language. This condition requires coordination and agreement between the West Sumatra Language Center as the technical implementing unit of the National Agency for Language Development and Cultivation so that language data in West Sumatra Province is no different or it can be said that fellow government agencies have the same data.

In addition, the naming of the Dharmasraya language in the table above can be refuted by the results of the verification of language mapping in this study. This is because the language use in Dharmasraya Regency does have differences. However, these differences are only limited to different dialects so that it can still be said to be a group from the Minangkabau language. This is indicated by the comparison of the dialectometric calculation of the Ampang Kuranji isolect and Sungai Limau isolects located in Dharmasraya Regency with the Pariangan isolect in Tanah Datar Regency as much as $31-50 \%$. In addition, the Mentawai language is not registered as having a dialect. Even though, Sunendar [5] The Mentawai language has three dialects, namely the North Siberut dialect, the South Siberut dialect, and the Sipora Pagai dialect. Thus, the data from the local government needs to be proven in dialectological linguistic research such as this study so that the linguistic data has a strong basis.

\section{CONCLUSION}

The results of this study can be concluded that the Minangkabau language has two dialects, namely the Agam-Tanah Datar dialect and Pancung Soal dialect with the percentage of the dialectometry calculation results of 51-80\%. The Agam-Tanah Datar dialect consists of the Payakumbuh subdialect, Limapuluh Kota subdialect, Pangkalan Koto Baru subdialect, Pasaman subdialect, and Tarung-Tarung Rao subdialects, while the Pancung Soal dialect consists of the Koto Baru subdialect, Sungai Limau subdialect, and Lunang subdialects. The subdialect classification can be seen from the results of the $31-50 \%$ dialectometry calculation. The boundaries of the Minangkabau dialect in West Sumatra Province are also clearly illustrated from the language map made in this study. However, this result still needs to be proven again in the future with more and more data.

On the other hand, language data, especially the Minangkabau language, is still not uniform. This can be seen from the different dialect names, both from previous research and data from local governments. Coordination and agreement between the West Sumatra Provincial Government and the West Sumatra Language Center as a representative of the National Agency for Language Development and Cultivation is very necessary in the future. This difference in language data makes people as data users confused about choosing the right reference. The coordination and agreement on the number and naming of the Minangkabau dialect is not only through discussion, but it is still necessary to prove this kind of study so that the basis for the decision is strong.

\section{REFERENCES}

[1] Budiono, S. (2018). Ancient Javanese Vocabulary Tracking: Case Studies in Tambak Banyumas Subdistrict and Glagah Banyuwangi District Based on Dialectological Studies. University of Indonesia.

[2] Eckert, P. (2012). Three waves of variation study: The emergence of meaning in the study of sociolinguistic variation. Annual Review of Anthropology, 41(June), 87-100. https://doi.org/10.1146/annurev-anthro-092611145828

[3] Maksan, M., Kasim, Y., Medan, T., Arifin, S., Basri, \& Sikumbang, AR (1984). Minangkabau dialect geography. Jakarta: Ministry of Education and Culture.

[4] Wahyudi, et al. (2009). Kinship and Mapping of Languages in West Sumatra Province. Padang City: Language Center of West Sumatra Province.

[5] Sunendar, D. (2019). Language and Language Maps in Indonesia (6th ed.). Jakarta: Language Development and Development Agency, Ministry of Education and Culture.

[6] Lauder, MR (2007). Overview of Language Mapping. Jakarta: Akbar Media Eka Sarana 
[7] Ayatrohaedi. (2002). Dialectology Research Guidelines. Language Center of the Ministry of National Education.

[8] West Sumatra Provincial Government. (2018). Main Thoughts of Regional Culture of West Sumatra Province. Padang City: Department of Culture of West Sumatra Province. 